\title{
Chromosome Banding in Amphibia. XXXIII. Demonstration of 5-Methylcytosine-Rich Heterochromatin in Anura
}

\author{
Michael Schmid Claus Steinlein \\ Department of Human Genetics, University of Würzburg, Würzburg, Germany
}

\author{
Key Words \\ Anura $\cdot$ Heterochromatin $\cdot$ Hypermethylated DNA . \\ Immunofluorescence $\cdot 5$-Methylcytosine
}

\begin{abstract}
An experimental approach using monoclonal anti-5-methylcytosine (5-MeC) antibodies and indirect immunofluorescence was elaborated for detecting $5-\mathrm{MeC}$-rich chromosome regions in anuran chromosomes. This technique was applied to mitotic metaphases of 6 neotropical frog species belonging to 6 genera and 4 families. The hypermethylation patterns were compared with a variety of banding patterns obtained by conventional banding techniques. The hypermethylated DNA sequences are species-specific and located exclusively in constitutive heterochromatin. They are found in centromeric, pericentromeric, telomeric, and interstitial positions of the chromosomes and adjacent to nucleolus organizer regions. 5-MeC-rich DNA sequences can be embedded both in AT- and GC-rich repetitive DNA. The experimental parameters that have major influence on the reproducibility and quality of the anti-5-MeC antibody labeling are discussed.
\end{abstract}

The constitutive heterochromatin in the chromosomes of numerous anuran species has been exhaustively examined by a variety of cytogenetic techniques, including C-banding, staining with DNA base pair-specific fluorochromes, fluorescence counterstaining (i.e., fluorochromes that are combined with other fluorochromes or with non-fluorescent substances), BrdU replication banding, restriction endonuclease treatment, and in situ hybridization using repetitive DNA probes [for reviews, see Schmid et al., 2010, 2012]. Comparisons of heterochromatic patterns at an interspecific level have contributed valuable details for anuran cytotaxonomy. It has been demonstrated that, although many species of the various anuran genera share similarity in chromosome number and morphology, there can be extensive differences in the position and amount of heterochromatin [Schmid, 1978a, b, 1980; Schmid et al., 1987, 1990; King, 1990; Green and Sessions, 2007]. Evidently, chromosomal locations and amounts of heterochromatic regions are highly variable and change rapidly in the course of evolution [John, 1988]. As emphasized by King [1990], C-band patterns have significantly contributed to the differentiation of karyotypes between related species, and observed differences in the position and content of constitutive heterochromatin between amphibian karyotypes show that not even 2 species in the most related taxa which have been studied possess identical C-band patterns. Thus,

\section{KARGER}

E-Mail karger@karger.com

www.karger.com/cgr
(C) 2016 S. Karger AG, Basel

$1424-8581 / 16 / 1481-0035 \$ 39.50 / 0$
Michael Schmid

Department of Human Genetics, University of Würzburg

Biozentrum, Am Hubland

DE-97074 Würzburg (Germany)

E-Mail m.schmid@biozentrum.uni-wuerzburg.de 
Table 1. The 6 anuran species examined, collection sites, and number of specimens analyzed

\begin{tabular}{|c|c|c|c|c|c|}
\hline Family & Species & Country & Locality of sampling & $\begin{array}{l}\text { Geographical } \\
\text { coordinates }\end{array}$ & Specimens \\
\hline Craugastoridae & Craugastor fitzingeri & Costa Rica & $\begin{array}{l}\text { Cabo Blanco Natural Reserve, Península de Nicoya, 0-30 m } \\
\text { elevation, Puntarenas Province }\end{array}$ & $09^{\circ} 35^{\prime} \mathrm{N} / 85^{\circ} 07^{\prime} \mathrm{W}$ & $1 \sigma^{\prime}, 1$ 우 \\
\hline Eleutherodactylidae & $\begin{array}{l}\text { Eleutherodactylus } \\
\text { planirostris }\end{array}$ & Cuba & $\begin{array}{l}\text { Santo Domingo, borderland of the Pico Turquino National } \\
\text { Park, Sierra Maestra, } 225 \text { m elevation, Granma Province }\end{array}$ & $20^{\circ} 02^{\prime} \mathrm{N} / 76^{\circ} 54^{\prime} \mathrm{W}$ & $1 \sigma^{x}, 1$ 우 \\
\hline \multirow[t]{2}{*}{ Hemiphractidae } & Gastrotheca walkeri & Venezuela & $\begin{array}{l}\text { Henri Pittier National Park, surroundings of the biological field } \\
\text { station 'Rancho Grande', } 920-1,180 \text { m elevation, Aragua State }\end{array}$ & $10^{\circ} 21^{\prime} \mathrm{N} / 67^{\circ} 41^{\prime} \mathrm{W}$ & 29 \\
\hline & Stefania scalae & Venezuela & $\begin{array}{l}\text { Salto Danto waterfall, } \mathrm{km} 107 \text { on the road from El Dorado to } \\
\text { Santa Elena de Uairén, 1,460 m elevation, Bolivar State }\end{array}$ & $05^{\circ} 58^{\prime} \mathrm{N} / 61^{\circ} 22^{\prime} \mathrm{W}$ & $10^{\prime \prime}, 1$ 우 \\
\hline \multirow[t]{2}{*}{ Hylidae } & Hypsiboas boans & Venezuela & $\begin{array}{l}\text { km } 99 \text { on the road from El Dorado to Santa Elena de Uairén, } \\
\sim 260 \text { m elevation, Bolivar State }\end{array}$ & $06^{\circ} 04^{\prime} \mathrm{N} / 61^{\circ} 24^{\prime} \mathrm{W}$ & $10^{x}$ \\
\hline & $\begin{array}{l}\text { Osteopilus } \\
\text { septentrionalis }\end{array}$ & Cuba & $\begin{array}{l}\text { Reserva Ecológica Rancho Azucarero, Artemisa, La Habana } \\
\text { Province }\end{array}$ & $22^{\circ} 50^{\prime} \mathrm{N} / 82^{\circ} 49^{\prime} \mathrm{W}$ & 19 \\
\hline
\end{tabular}

comparison of species belonging to the anuran genera Bufo [Schmid, 1978a; Matsui et al., 1985; Miura, 1995], Rana [Schmid, 1978b], Gastrotheca [Schmid et al., 2012], Litoria [King, 1980], and to the large unranked taxon Terrarana [Schmid et al., 2010] demonstrate a striking Cband variation in species with essentially the same karyotype.

In mammals, birds and fishes, microscopically detectable 5-methylcytosine (5-MeC)-rich repetitive DNA sequences are restricted to a subset of the heterochromatic regions present in the karyotypes [Miller et al., 1974; Schnedl et al., 1975, 1976; Schreck et al., 1974, 1977; Schmid et al., 2015a-c]. These very distinct chromosomal markers are species-specific and, therefore, quite useful for comparative cytogenetics in all vertebrate taxa. Even phylogenetically closely related species of birds and fishes with the same diploid number, chromosome morphology and C-banding patterns show different hypermethylation patterns [Schmid et al., 2015a, c].

Up to date, no cytogenetic analyses on the occurrence of 5-MeC-rich regions have been carried out in amphibians. In the present study, the amounts and positions of 5 -MeC-rich chromosome regions were detected in 6 neotropical anuran species belonging to 4 families and to the genera Craugastor, Eleutherodactylus, Gastrotheca, Stefania, Hypsiboas, and Osteopilus using indirect immunofluorescence and highly specific monoclonal anti-5-MeC antibodies. The hypermethylation patterns of their karyotypes were compared with a variety of banding patterns obtained by conventional cytogenetic techniques. The experimental parameters influencing reproducibility and quality of the anti-5-MeC antibody labeling are presented.

\section{Materials and Methods}

\section{Animals}

Adult individuals of Craugastor fitzingeri $\left(10^{*}, 19\right)$, Eleutherodactylus planirostris (10', 19), Gastrotheca walkeri (2\%), Stefania scalae $\left(10^{\prime \prime}, 1 \%\right)$, Hypsiboas boans $\left(10^{7}\right)$, and Osteopilus septentrionalis (19) were obtained during several expeditions to Costa Rica, Cuba, and Venezuela. The exact collection sites and the number of specimens examined are shown in table 1. The chromosomes of the frogs were prepared in temporary cytogenetic laboratories established in the Department of Biology, University of Costa Rica, San José (Costa Rica), in the Department of Animal and Human Biology, University of La Habana, La Habana (Cuba), and in the field station 'Estación Biológica de Rancho Grande' located in the Henri Pittier National Park, Aragua State (Venezuela). The fixed material was transferred to $1.8-\mathrm{ml}$ plastic tubes (Nunc), stored at 4 or $-20^{\circ} \mathrm{C}$ and transported to the laboratory in Würzburg (Germany) for cytogenetic analyses either packed in dry ice or at room temperature.

\section{Chromosome Preparations}

Mitotic chromosomes were prepared directly from bone marrow and intestine after in vivo colchicine treatment. Detailed techniques used for cell suspensions, as well as the hypotonic treatment and fixation of the cells have been described previously [Schmid et al., 2010]. The fixed cell suspensions and/or chromosome slides were kept at 4 or $-20^{\circ} \mathrm{C}$ for variable periods before banding analyses and detection of hypermethylated heterochromatic regions were performed.

\section{Banding Analyses of Chromosomes}

C-banding, staining with quinacrine mustard, DAPI or Hoechst 33258, fluorescence counterstaining with distamycin A/ mithramycin or distamycin A/DAPI, and labeling of the nucleolus organizer regions (NORs) with $\mathrm{AgNO}_{3}$ were performed according to the methods described by Schmid et al. [2010]. Microscopic analyses were conducted using Zeiss photomicroscopes III, fluorescence microscopes and Axiophot microscopes
Schmid/Steinlein 


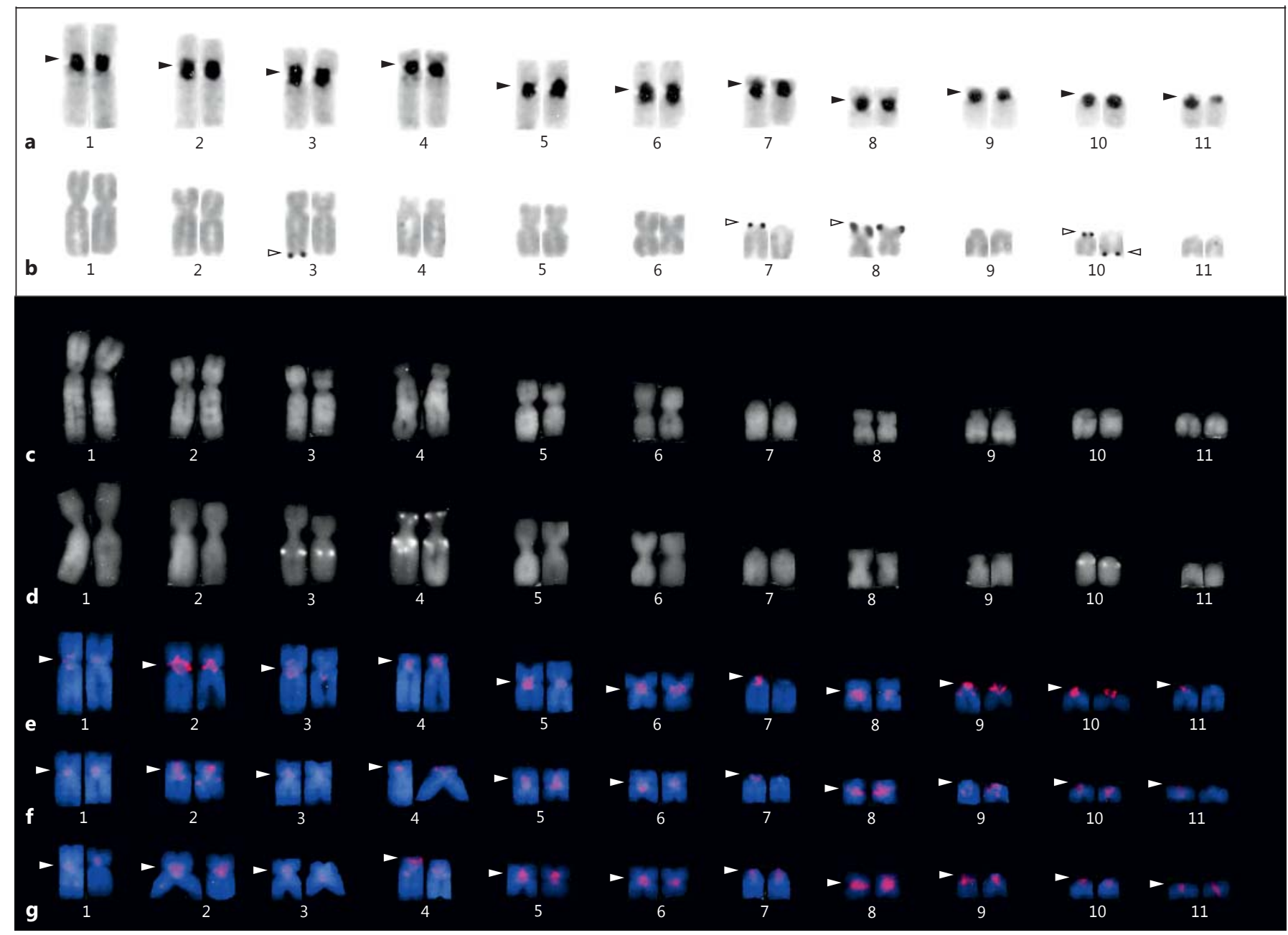

Fig. 1. Karyotypes of Craugastor fitzingeri showing C-bands (a), silver staining (b), quinacrine mustard fluorescence (c), distamycin A/DAPI counterstaining (d) and indirect immunofluorescence using a monoclonal antibody against 5- $\mathrm{MeC}(\mathbf{e}-\mathbf{g})$. The 5-MeC-rich heterochromatic regions show red fluorescence signals, the chromosomes are stained blue with DAPI. The filled arrowheads in a and $\mathbf{e}-\mathbf{g}$ indicate the $5-\mathrm{MeC}$-rich heterochromatic regions, the open arrowheads in $\mathbf{b}$ the multiple NORs in this species. equipped with incident HBO 50W mercury lamp illumination. The filter combinations necessary for the analyses of metaphases stained with the various fluorochromes were described by Schmid et al. [2010].

\section{Detection of Hypermethylated Heterochromatic Chromosome} Regions

Hypermethylated DNA was detected by the technique of indirect immunofluorescence using monoclonal antibodies against 5 -MeC. The slides with the chromosome preparations were immersed $1 \mathrm{~cm}$ below the level of a buffer solution (PBS) and denatured by UV-light irradiation for $2.5-3 \mathrm{~h}$ at a distance of $10 \mathrm{~cm}$ from a UV lamp (254 nm). For indirect immunofluorescence, the slides were first incubated for $1 \mathrm{~h}$ in a coplin jar with blocking solution (PBS, with $0.3 \%$ BSA, $0.1 \%$ Tween) and then with $50 \mu \mathrm{l}$ of a monoclonal mouse anti-5-MeC (primary) antibody [Im- print ${ }^{\circledR}$ monoclonal anti-5-methylcytosine (33D3) antibody, Sigma-Aldrich] diluted 1:1,000 with the blocking solution in a humidified incubator at $37^{\circ} \mathrm{C}$ for $1 \mathrm{~h}$. A non-siliconized coverslip $(22 \times 60 \mathrm{~mm})$ was placed on the $50-\mu l$ drop to spread the anti5 - MeC antibody over the complete slide surface. Subsequently, the slides were washed twice in PBS (with $0.3 \%$ BSA) for 3 min each and then incubated with $70 \mu \mathrm{l}$ of the secondary antibody (TRITC-conjugated rabbit anti-mouse IgG, Sigma-Aldrich) diluted 1:200 with PBS. The incubation conditions were as with the primary antibody. After 2 further washes with PBS for 3 min each, the chromosome preparations were mounted in Vectashield ${ }^{\circledR}$ mounting medium with DAPI (Vector Laboratories). Image analysis was performed with Zeiss epifluorescence microscopes equipped with thermoelectronically cooled charge-coupled device cameras (Applied Spectral Imaging) using easyFISH 1.2 software. 


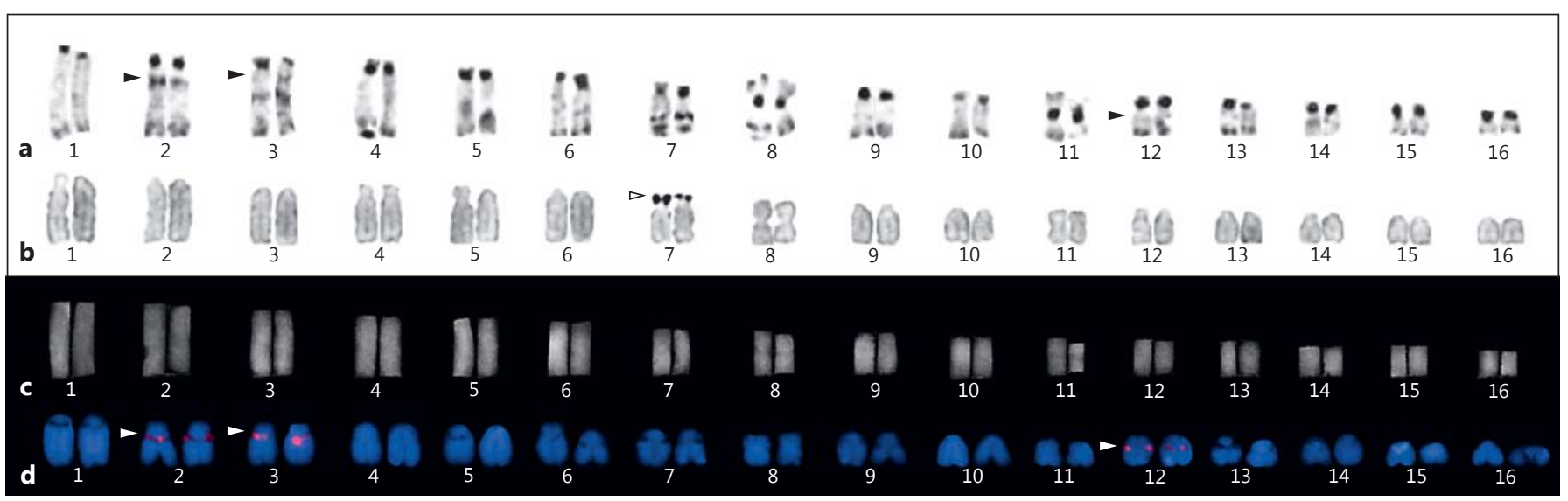

Fig. 2. Karyotypes of Eleutherodactylus planirostris showing Cbands (a), silver staining (b), quinacrine mustard fluorescence (c), and indirect immunofluorescence using a monoclonal antibody against $5-\mathrm{MeC}(\mathbf{d})$. The $5-\mathrm{MeC}$-rich heterochromatic re- gions show red fluorescence signals, the chromosomes are stained blue with DAPI. The filled arrowheads in $\mathbf{a}$ and $\mathbf{d}$ indicate the 5-MeC-rich heterochromatic regions, the open arrowhead in $\mathbf{b}$ the NOR.

\section{Results and Discussion}

\section{Karyotypes}

The chromosome complements of all frog species examined in the present study have been published previously. Details on conventionally stained and banded karyotypes of C. fitzingeri and E. planirostris were presented by Schmid et al. [2010], of G. walkeri and S. scalae by Schmid et al. [2002, 2012], of $H$. boans by de Mattos et al. [2014], and of O. septentrionalis by Anderson [1996]. In all karyotypes, distinctly stained constitutive heterochromatin is located in the centromeric and pericentromeric regions of all chromosomes. As is the case in most anuran species, telomerically and interstitially located heterochromatin is stained less intensely (figs. 1-6). Multiple NORs in the telomeric regions of a variable number of chromosomes are found in the karyotype of $C$. fitzingeri (fig. 1b) [Schmid et al., 2012]. Sex chromosomes of the XX⿻/XYơ type are present in G. walkeri (fig. 3a) [Schmid et al., 2002, 2012].

\section{5-MeC-Rich Heterochromatin}

In the karyotypes of the frogs studied, various chromosome regions with brightly fluorescing signals are obtained by anti-5-MeC antibody labeling (figs. 1-6). The numbers and locations of fluorescing signals in the karyotypes are constant and species-specific. Thus, the karyotype of $C$. fitzingeri shows 22 fluorescing signals, one each in the centromeric or pericentromeric region of all 11 chromosome pairs (fig. 1e-g). Also in the karyotype of $O$. septentrionalis, 22 hybridization signals can be recognized, but these are located in the telomeric regions of 7 chromosome pairs. Two additional signals are found in the centromeric region of the smallest chromosome pair (fig. 6b). In contrast, the telomeric regions of only 2 chromosome pairs are brightly fluorescing in the karyotype of G. walkeri (fig. $3 \mathrm{e}-\mathrm{g}$ ). The comparison between the chromosomes exhibiting the brightly fluorescing anti-5-MeC antibody signals and their C-banding patterns shows that all the hypermethylated regions consist of constitutive heterochromatin (figs. 1-6). Small fluorescent signals apparently located in the euchromatic chromosome segments of few metaphases are background artifacts caused by insufficient washing of the chromosome preparations after incubation with the TRITC-conjugated secondary antibody.

The sizes and fluorescence intensities of the anti$5-\mathrm{MeC}$ antibody signals are specific for the respective heterochromatic regions in the karyotypes. This most probably reflects the amounts of hypermethylated DNA sequences present in them. Thus, in C. fitzingeri, the centromeric or pericentromeric heterochromatin of chromosomes 2 and 3-8 fluoresce distinctly brighter than those in chromosomes 1 and 3 (fig. 1e-g). Actually, the fluorescence signals in the latter 2 chromosome pairs are at the limit of microscopical resolution.

The chromosomal distribution of 5-MeC-rich heterochromatin in the anurans examined is highly variable. Thus, in C. fitzingeri, E. planirostris and S. scalae, it is located in centromeric and pericentromeric regions of 11 , 


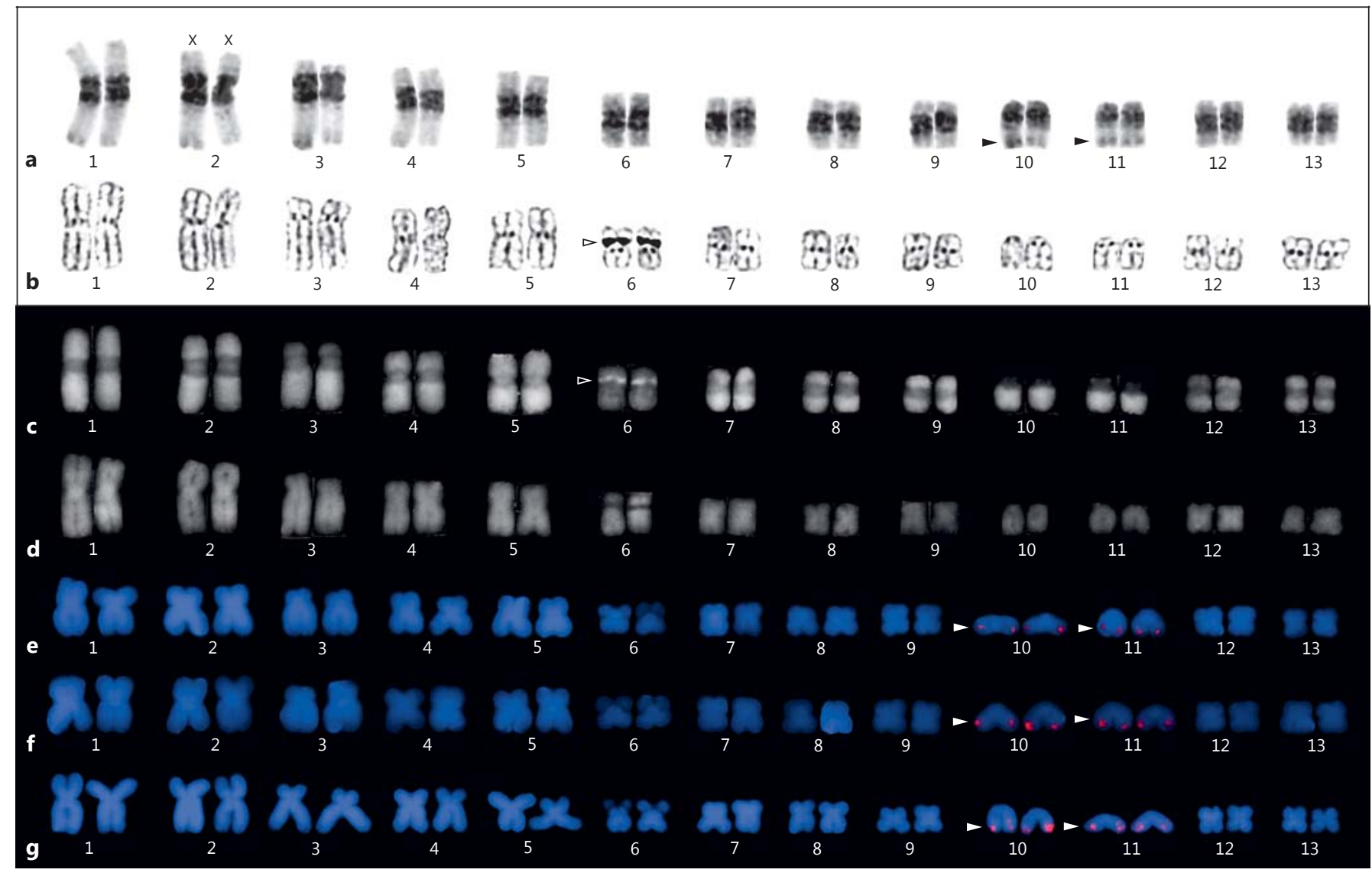

Fig. 3. Karyotypes of female Gastrotheca walkeri showing C-bands (a), silver staining (b), distamycin A/mithramycin counterstaining (c), quinacrine mustard fluorescence (d), and indirect immunofluorescence using a monoclonal antibody against 5-MeC (e-g). The 5-MeC-rich heterochromatic regions show red fluorescence

3 and 8 chromosome pairs, respectively (figs. 1e-g, 2d, 4f, $\mathrm{g}$ ), whereas in G. walkeri it is restricted to subtelomeric or telomeric regions in the long arms of 2 telocentric chromosome pairs (fig. 3e-g). In H. boans, it is found in centromeric or pericentromeric regions of chromosomes 1 and 3 , in an interstitial position in the long arm of chromosome 10 as well as at the NOR in the chromosome 7 long arm (fig. 5h, i). Finally, in O. septentrionalis, 5-MeCrich DNA sequences are recognized in the telomeric and subtelomeric regions of 7 chromosome pairs and in the centromeric regions of the smallest chromosome pair (fig. 6b).

Heterochromatic regions showing bright fluorescence after staining with quinacrine mustard, DAPI, and Hoechst 33258 or after counterstaining with distamycin A/DAPI are believed to be rich in AT base pairs, whereas fluorescence staining with mithramycin or counterstain-

Chromosome Banding in Amphibia. XXXIII.

5-MeC-Rich Heterochromatin in Anura signals, the chromosomes are stained blue with DAPI. The filled arrowheads in $\mathbf{a}$ and $\mathbf{e - g}$ indicate the $5-\mathrm{MeC}$-rich heterochromatic regions, the open arrowheads in $\mathbf{b}$ and $\mathbf{c}$ the NOR. The chromosomes 2 are the homomorphic XX sex chromosomes (see a).

ing with distamycin $\mathrm{A} /$ mithramycin specifically labels GC-rich heterochromatic regions [for review, see Schmid et al., 2010]. The comparison of the fluorescence patterns induced with these fluorochromes and the hypermethylation patterns in the karyotypes of the 6 anuran species shows that $5-\mathrm{MeC}$-rich DNA sequences can be embedded both in AT- and GC-rich repetitive DNA. Thus, in H. boans, the hypermethylated sequences in chromosomes 1,3 and 10 are within AT-rich heterochromatin, whereas the NOR-associated hypermethylated sequences in chromosome 7 are within GC-rich heterochromatin (compare karyotypes in fig. $5 \mathrm{a}-\mathrm{i}$ ). It is important to note that UVirradiation is particularly effective in generating singlestranded regions in the DNA which is rich in AT base pairs with adjacent pyrimidines [Miller et al., 1974; Schreck et al., 1974], a site where the anti-5-MeC antibody can attach. 


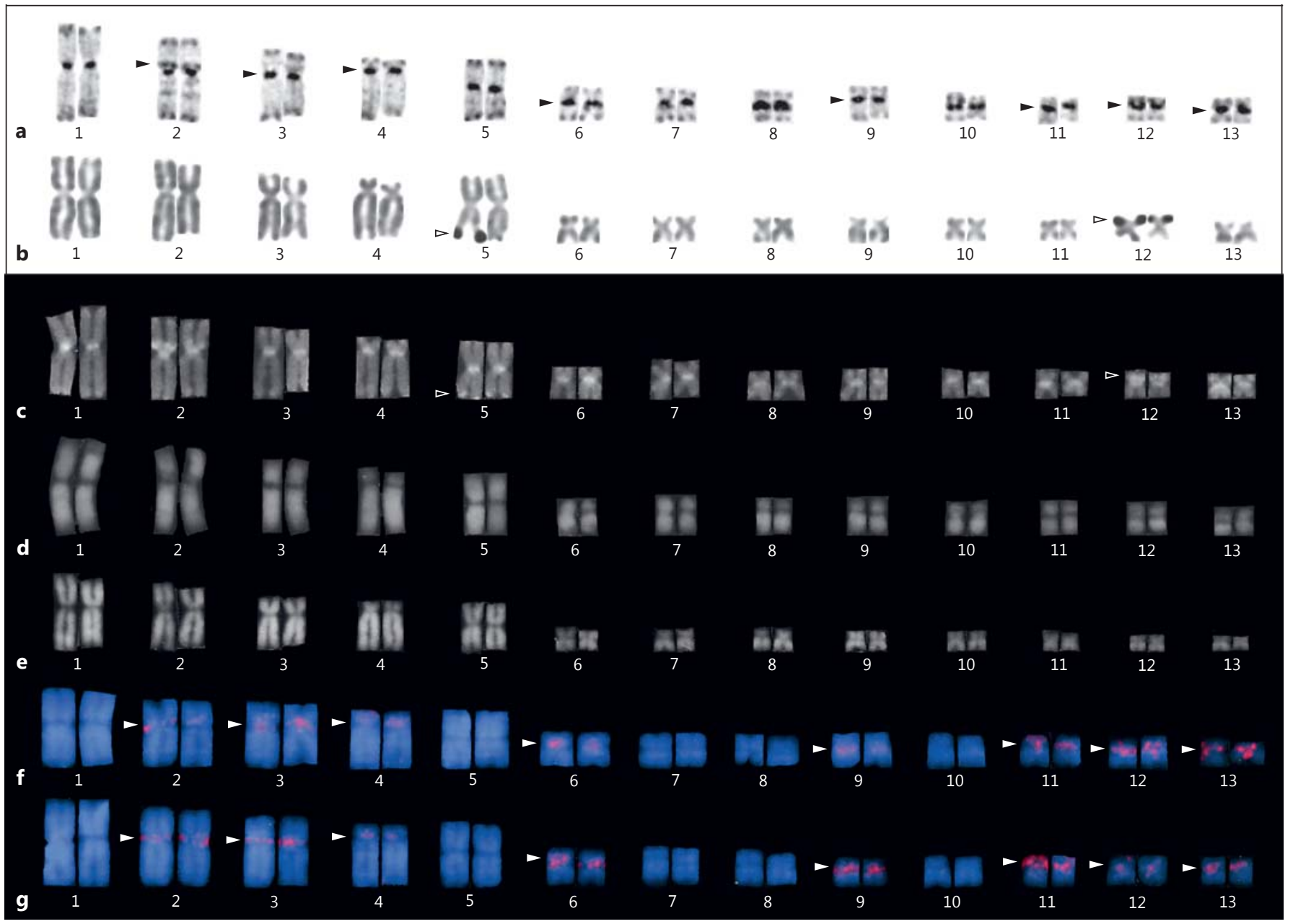

Fig. 4. Karyotypes of Stefania scalae showing C-bands (a), silver staining (b), distamycin A/mithramycin counterstaining (c), quinacrine mustard fluorescence (d), direct DAPI staining (e), and indirect immunofluorescence using a monoclonal antibody against
5-MeC (f, g). The 5-MeC-rich heterochromatic regions show red fluorescence signals, the chromosomes are stained blue with DAPI. The filled arrowheads in $\mathbf{a}, \mathbf{f}$ and $\mathbf{g}$ indicate the 5-MeC-rich heterochromatic regions, the open arrowheads in $\mathbf{b}$ and $\mathbf{c}$ the NORs.
In S. scalae, all 8 hypermethylated regions are embedded in distamycin $\mathrm{A} /$ mithramycin-positive heterochromatin (compare karyotypes in fig. $4 \mathrm{a}-\mathrm{g}$ ).

In the karyotype of $C$. fitzingeri (fig. 1), the 3 brilliant distamycin A/DAPI-positive heterochromatic regions in the pericentromeric, interstitial and telomeric regions of chromosomes 3 and 4 are not hypermethylated (compare karyotypes in fig. 1d-g). It is well known that modification of DAPI banding on chromosomes by prestaining with the DNA-binding oligopeptide antibiotic distamycin A reveals a specific subset of AT base pair-rich heterochromatin [Sumner, 1990]. Schweizer et al. [1978] noted that the distamycin A/DAPI-positive heterochromatic regions in human chromosomes correspond exactly to those sites enriched in 5-methylcytosine [Miller et al., 1974; Lubit et al., 1976; Schnedl et al., 1976]. However, this correlation cannot be generalized because, for example, the highly repetitive satellite DNA of the mouse (Mus musculus) is highly methylated, but not distamycin A/ DAPI-positive [Schnedl et al., 1980].

The fluorescence patterns obtained by immunofluorescence experiments are fairly well reproducible. The fixation time of the cell suspensions (up to 12 years), the temperature at which the fixed cells suspensions are kept ( 4 and $-20^{\circ} \mathrm{C}$ ), and the incubation time with the primary and secondary antibodies (1-5 h) have little influence on the quality of fluorescing signals. However, the age of airdried chromosome slides has negative effects on the im-
40

Cytogenet Genome Res 2016;148:35-43 DOI: $10.1159 / 000446141$
Schmid/Steinlein 


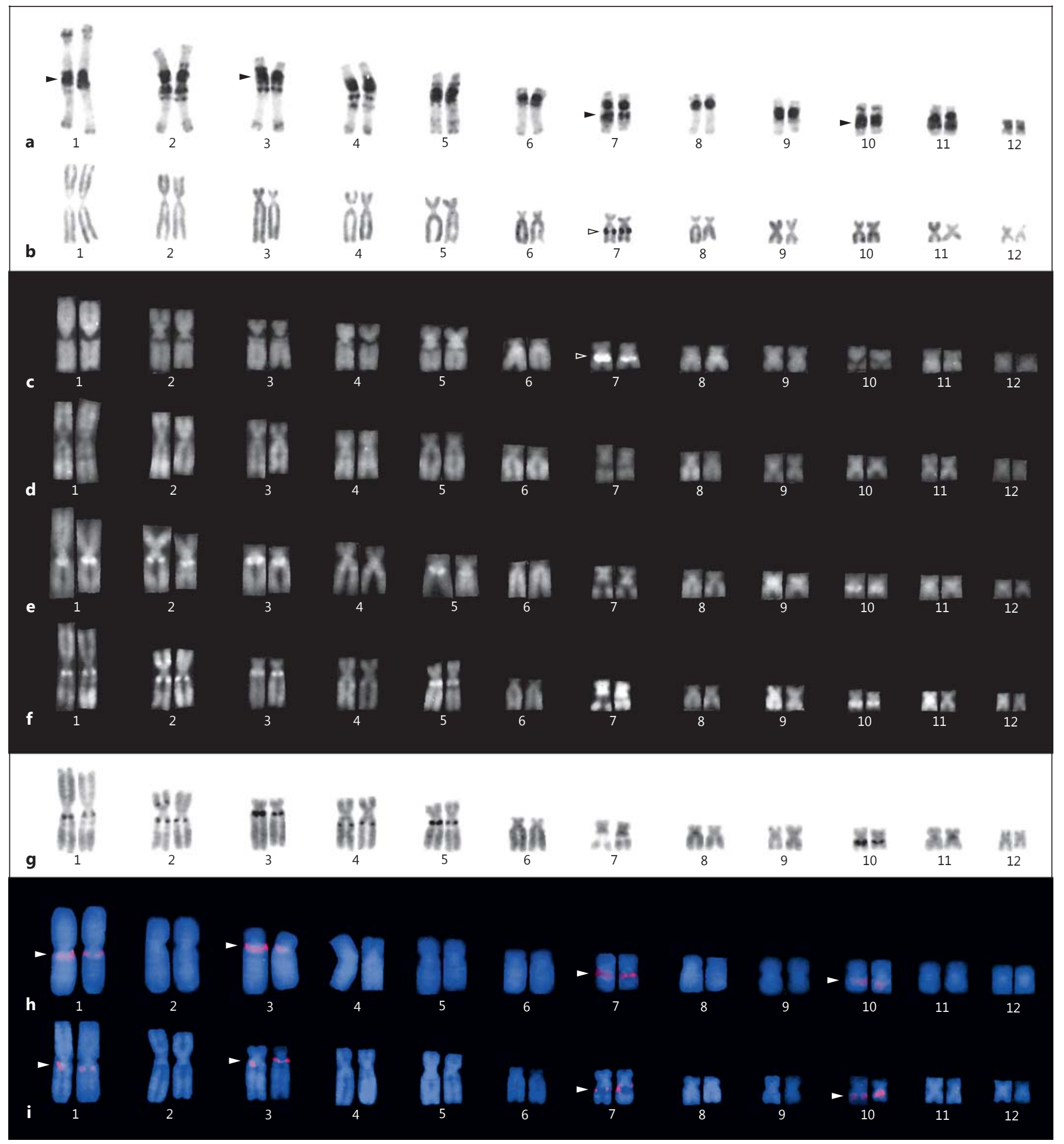

Fig. 5. Karyotypes of Hypsiboas boans showing C-bands (a), silver staining (b), distamycin A/mithramycin counterstaining (c), quinacrine mustard fluorescence (d), direct DAPI staining (e), Hoechst 33258 fluorescence (f), an inverted image of the Hoechst 33258-stained chromosomes (g), and indirect immunofluores- cence using a monoclonal antibody against $5-\mathrm{MeC}(\mathbf{h}, \mathbf{i})$. The 5-MeC-rich heterochromatic regions show red fluorescence signals, the chromosomes are stained blue with DAPI. The filled arrowheads in $\mathbf{a}, \mathbf{h}$ and $\mathbf{i}$ indicate the 5-MeC-rich heterochromatic regions, the open arrowheads in $\mathbf{b}$ and $\mathbf{c}$ the NORs. 


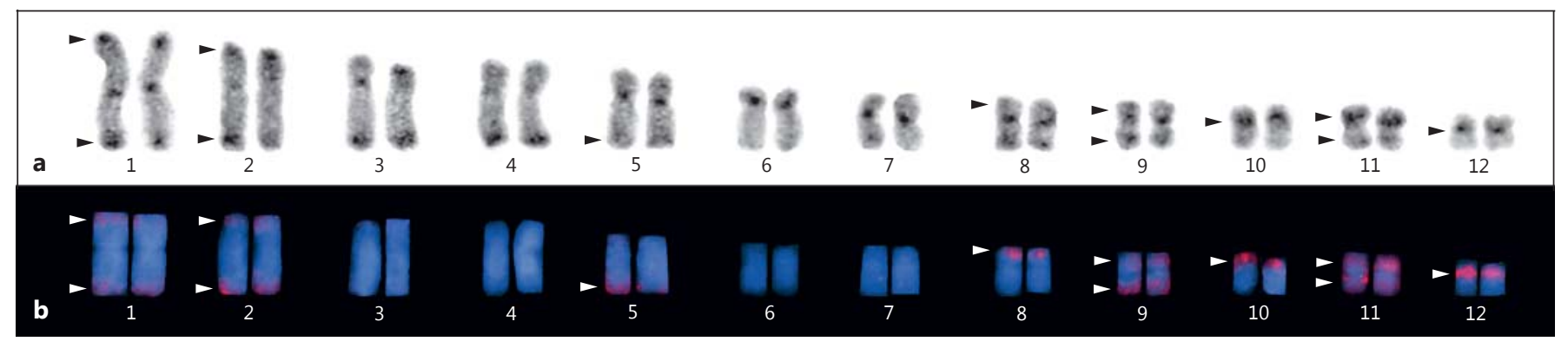

Fig. 6. Karyotypes of Osteopilus septentrionalis showing C-bands (a) and indirect immunofluorescence using a monoclonal antibody against $5-\mathrm{MeC}(\mathbf{b})$. The $5-\mathrm{MeC}$-rich heterochromatic regions show red fluorescence signals, the chromosomes are stained blue with DAPI. The arrowheads indicate the 5-MeC-rich heterochromatic regions. munolabeling quality. Chromosomes that do not anymore firmly adhere to the surface of the slides but are partially detached are prone to labeling artifacts. Furthermore, the quality of the antibodies, the time of UVlight irradiation of chromosome preparations, and the washing procedures after incubation with the primary and secondary antibody are important factors which influence the anti-5-MeC antibody labeling. The present study revealed that not in all metaphases analyzed the complete set of $5-\mathrm{MeC}$-rich heterochromatin becomes apparent. The larger a hypermethylated heterochromatic region is, the more metaphases exhibit the specific anti-5-MeC antibody fluorescence of this region. But minor hypermethylated heterochromatic regions can escape detection by immunolabeling. It is therefore recommended to examine at least 15-20 high-quality immunolabeled metaphases before any conclusion is drawn on the consistency of heterochromatin hypermethylation patterns in karyotypes of anuran species. The fluorescence signals of the secondary antibody are stable which allows repeated examination of the preparations and long photographic exposure times in the case of small and weak fluorescing signals. The preparations can be stored in the dark at room temperature or in a freezer at $4^{\circ} \mathrm{C}$.

Like in mammals, birds and fishes [Miller et al., 1974; Schreck et al., 1974, 1977; Schnedl et al., 1975, 1976; Schmid et al., 2015a-c], 5-MeC-rich repetitive DNA sequences are restricted to a subset of the heterochromatic regions present in the karyotypes of anurans. Furthermore, the hypermethylation patterns of constitutive heterochromatin in anuran karyotypes are highly variable but species-specific. Therefore, they are very useful as cytogenetic markers for easy and fast differentiation of related species with the same diploid chromosome number, chromosome morphology and classical banding patterns.

In the present study the karyotypes of a very limited number of anuran species were examined by anti-5-MeC antibody labeling. Considering the enormous diversity of heterochromatin in the karyotypes of anurans, especially those with differentiated and heterochromatic Y and $\mathrm{W}$ sex chromosomes, supernumerary B chromosomes, polyploid genomes, and multiple chromosomal polymorphisms [for reviews, see King, 1990; Schmid et al., 2010, 2012], multitudinous new data on anuran cytogenetics and karyosystematics can be expected. This technique is also anticipated to have applications in the characterization of constitutive heterochromatin in the karyotypes of newts and salamanders (order Urodela) and caecilians (order Apoda). Finally, it will be of interest to examine whether the hypermethylation patterns of constitutive heterochromatin actually constitute a stable intraspecific feature or if tissue-specific patterns occur. In this respect, the examination of meiotic chromosomes, especially those in the lampbrush stage of female amphibians is particularly challenging.

\section{Acknowledgements}

We thank Dr. Pedro León (Costa Rica), Dr. Ana Sanz (Cuba), and Dr. Alberto Fernández Badillo (Venezuela) for logistic help during our expeditions to these countries. The careful immunocytogenetic analyses of Ellina Schultz, and the very expert and reliable photographic assistance of Gitta Hesse are highly appreciated. This study was financially supported by the German Research Foundation DFG (grants Schm 484/6-1, 7-1, 10-1, 15-1, 15-2) and the Volkswagen Foundation (grant VW/I/72 515).
Schmid/Steinlein 


\section{Statement of Ethics}

All procedures with the living animals strictly conformed to the guidelines established by the Animal Care Committees of the respective countries.

\section{Disclosure Statement}

The authors have no conflicts of interest to declare.

\section{References}

Anderson K: A karyological perspective on the monophyly of the hylid genus Osteopilus, in Powell R, Henderson RW (eds): Contributions to West Indian Herpetology: A Tribute to Albert Schwartz, pp 157-168 (Society for the Study of Amphibians and Reptiles, New York 1996)

de Mattos TL, Coelho AC, Schneider CH, Telles DOC, Menin M, Gross MC: Karyotypic diversity in seven Amazonian anurans in the genus Hypsiboas (family Hylidae). BMC Genet 15: 43 (2014).

Green DM, Sessions SK: Karyology and cytogenetics, in Heatwole H, Tyler M (eds): Amphibian Biology, vol 7 (Surrey Beatty \& Sons, Chipping Norton 2007).

John B: The biology of heterochromatin, in Verma RS (ed): Heterochromatin. Molecular and Structural Aspects, pp 1-147 (Cambridge University Press, Cambridge 1988).

King M: C-banding studies on Australian hylid frogs: secondary constriction structure and the concept of euchromatin transformation. Chromosoma 80:191-217 (1980).

King M: Amphibia, in John B (ed): Animal Cytogenetics, vol 4/2 (Gebrüder Borntraeger, Berlin 1990).

Lubit BW, Pham TD, Miller OJ, Erlanger BF: Localization of 5-methylcytosine in human metaphase chromosomes by immunoelectron microscopy. Cell 9:503-509 (1976).

Matsui M, Seto T, Kohsaka Y, Borkin LJ: Bearing of chromosome C-banding patterns on the classification of Eurasian toads of the Bufo bufo complex. Amphibia-Reptilia 6:23-33 (1985).

-Miller OJ, Schnedl W, Allen J, Erlanger BF: 5-Methylcytosine localised in mammalian constitutive heterochromatin. Nature 251: 636-637 (1974).
Miura I: Two differentiated groups of the Japanese toad, Bufo bufo japonicus, demonstrated by C-banding analysis of chromosomes. Caryologia 48:123-136 (1995).

Schmid M: Chromosome banding in Amphibia. I. Constitutive heterochromatin and nucleolus organizer regions in Bufo and Hyla. Chromosoma 66:361-388 (1978a).

Schmid M: Chromosome banding in Amphibia. II. Constitutive heterochromatin and nucleolus organizer regions in Ranidae, Microhylidae and Rhacophoridae. Chromosoma 68: 131-148 (1978b).

Schmid M: Chromosome evolution in Amphibia, in Müller H (ed): Cytogenetics of Vertebrates, pp 4-27 (Birkhäuser, Basel 1980).

Schmid M, Vitelli L, Batistoni R: Chromosome banding in Amphibia. XI. Constitutive heterochromatin, nucleolus organizers, $18 \mathrm{~S}+28 \mathrm{~S}$ and $5 \mathrm{~S}$ ribosomal RNA genes in Ascaphidae, Pipidae, Discoglossidae and Pelobatidae. Chromosoma 95:271-284 (1987).

Schmid M, Steinlein C, Nanda I, Epplen JT: Chromosome banding in Amphibia, in Olmo $\mathrm{E}$ (ed): Cytogenetics of Amphibians and Reptiles, pp 21-45 (Birkhäuser, Basel 1990).

Schmid M, Feichtinger W, Steinlein C, Nanda I, Mais C, et al: Chromosome banding in Amphibia. XXII. Atypical Y chromosomes in Gastrotheca walkeri and Gastrotheca ovifera (Anura, Hylidae). Cytogenet Genome Res 96: 228-238 (2002).

Schmid M, Steinlein C, Bogart JP, Feichtinger W, León $\mathrm{P}$, et al: The chromosomes of terraranan frogs. Insights into vertebrate cytogenetics. Cytogenet Genome Res 130/131:1-568 (2010).

Schmid M, Steinlein C, Bogart JP, Feichtinger W, Haaf T, et al: The hemiphractid frogs. Phylogeny, embryology, life history, and cytogenetics. Cytogenet Genome Res 138:69-384 (2012).

-Schmid M, Smith J, Burt DW, Aken BL, Antin PB, et al: Third Report on Chicken Genes and Chromosomes 2015. Cytogenet Genome Res 145:78-179 (2015a).
Schmid M, Steinlein C, Lomb C, Sperling K, Neitzel H: 5-Methylcytosine-rich heterochromatin in the Indian muntjak. Cytogenet Genome Res 147:240-246 (2015b).

Schmid M, Steinlein C, Yano CF, Cioffi MB: Hypermethylated chromosome regions in nine fish species with heteromorphic sex chromosomes. Cytogenet Genome Res 147:169-178 (2015c).

Schnedl W, Dev VG, Tantravahi R, Miller DA, Erlanger BF, Miller OJ: 5-Methylcytosine in heterochromatic regions of chromosomes: chimpanzee and gorilla compared to the human. Chromosoma 52:59-66 (1975).

-Schnedl W, Erlanger BF, Miller OJ: 5-Methylcytosine in heterochromatic regions of chromosomes in Bovidae. Hum Genet 31:21-26 (1976).

Schnedl W, Dann O, Schweizer D: Effects of counterstaining with DNA binding drugs on fluorescent banding patterns of human and mammalian chromosomes. Eur J Cell Biol 20: 290-296 (1980).

Schreck RR, Erlanger BF, Miller OJ: The use of antinucleoside antibodies to probe the organization of chromosomes denatured by ultraviolet irradiation. Exp Cell Res 88:31-39 (1974).

Schreck RR, Erlanger BF, Miller OJ: Binding of anti-nucleoside antibodies reveals different classes of DNA in the chromosomes of the kangaroo rat (Dipodomys ordii). Exp Cell Res 108:403-411 (1977).

-Schweizer D, Ambros P, Andrle M: Modification of DAPI banding on human chromosomes by prestaining with a DNA-binding oligopeptide antibiotic, distamycin A. Exp Cell Res 111: 327-332 (1978).

Sumner AT: Chromosome Banding (Unwin Hyman, London 1990). 